\title{
Reading and Writing Performance of Senior High School Students
}

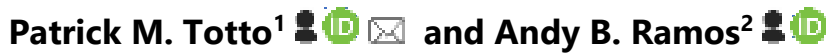 \\ ${ }^{1}$ Delfin Albano National High School, Isabela, Philippines \\ ${ }^{2}$ Isabela State University, Isabela, Philippines
}

$\triangle$ Corresponding Author: Patrick M. Totto, E-mail: totto.patrick@gmail.com

\section{ARTICLE INFORMATION}

Received: July 03, 2021

Accepted: September 15, 2021

Volume: 3

Issue: 9

DOI: 10.32996/ijels.2021.3.9.2

\section{KEYWORDS}

Reading performance, writing performance, reading attitude, writing attitude, senior highschool

\section{ABSTRACT}

The study was conducted to determine the performance and attitudes towards reading and writing of Grade 12 students in public schools of Cabagan, Isabela. There were 244 students involved in the study. Stratified random sampling was used in selecting the participants of the study. A quantitative research method was used in the study to determine performance and attitudes towards reading and writing. Frequency counts, percentage scores, the arithmetic mean, and Kendall's Rank Correlation Tau was used to describe and analyze the data in the study. The findings of the study revealed that students' reading and writing performance were poor. However, their attitudes toward reading and writing were positive. Hence, the study demonstrated that there is a significant correlation between students' attitudes and their reading and writing performance. Thus, the study supports DepEd's "SulongEdukalidad" in creating programs to enhance learners' reading mastery and sustain its basic goal of producing quality learners enhanced by quality education. Language teachers should also be engaged and exposed to training to handle weak foundations of learners in basic academic (reading and writing) skills.

\section{Introduction}

Individuals carry and develop the two most essential skills: reading and writing. Learning these skills contribute to success in daily living, especially for learners. The solid foundation for reading and writing is deeply engaged with determination for both teachers and students. As the education ladder progresses, the ability of learners to read and write also develops. This emphasizes the power of basic literacy among individuals.

According to Kern (2000), the term literacy is the capability to read and write, which are often focused at the beginning to intermediate stages of language learning, with literature and cultural learning being stressed at a higher degree. The modern perception of literacy, on the other hand, has shifted. The capability of reading and writing are no longer regarded as decisive elements in defining a person's knowledge. Scholars from rhetoric, writing, educational psychology, sociology, linguistics, and cultural theory argue for a more dynamic concept of literacy that includes both reading and writing.

Reading and writing are inextricably linked; good reading results in good writing, and good reading results in good writing (Stotsky, 1983). As a result, good authors also make good readers, whereas bad writers make bad readers (Hanane, 2015).

Reading skills become increasingly useful as students' progress through school, while the division between expert and incompetent readers is widening. Noor (2010) and Pretorius (2002) noted that reading is a crucial skill in any academic or higher learning environment that requires students to connect and digest ideas from books. He also emphasized that the number of first-year language learners attending higher education institutions is not prepared because of the reading demands and numerous challenges. As a result, academic success is dependent on students' knowledge of and use of reading strategies.

K C AL-KINDI CENTER

R D FOR RESEARCH AND DEVELOPMENT

Your goteway to world-class research

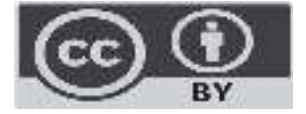

Published by Al-Kindi Center for Research and Development. Copyright (c) the author(s). This open access article is distributed under a Creative Commons Attribution (CC-BY) 4.0 license 
Students "join postsecondary institutions with limited reading experience and skills," according to Livingston et al. (2015). Thus, making it difficult for them to comprehend literature at this level. Students must, however, be able to read at both the low and high levels, including comprehension, assessment, integration, and synthesis of information, as well as critical reading. This means that reading academic literature is seen as a required skill for university students.

Aside from reading, many students have difficulty writing. According to Jamaludin\& Mohamed (2006), students are unable to write to the desired benchmark set due to a lack of general knowledge to extend and expound the concerns provided in their writing. Language accuracy, which encompasses spelling, punctuation, morphology, and syntax, is another obvious issue that students encounter (Sabar\&Zamri, 2008). As a result, reading and writing have become a severe problem for tertiary students.

Basic writing patterns are difficult for second-language learners to master. According to Cabansag (2013), the majority of students at the State University of Cagayan make the most mistakes in grammar and mechanics in their papers, particularly in the usage of verbs and verb tenses and capitalization regulations. Furthermore, as evidenced in the classroom, many students continue to struggle with reading comprehension and writing.

The researcher became interested in conducting this study to improve and develop learners' skills and abilities in reading comprehension and writing as a result of the aforementioned challenges and concerns regarding students' reading and writing performance.

\subsection{Statement of the Problem}

The research investigated the reading and writing performance of Grade 12 learners. Specifically, it seeks to find answers to the following questions:

1. What is the reading performance of Grade 12 students?

2. What is the writing performance of Grade 12 students in terms of:

a. grammar; and

b. mechanics?

3. What is the attitude of Grade 12 students towards:

a. reading; and

b. writing?

4. What is the academic performance of Grade 12 students in the Reading and Writing subject?

5. Is there a significant relationship between:

a. the attitude of the students towards reading and their reading performance; and

b. the attitude of the students towards writing and their writing performance?

\subsection{Significance of the Study}

This study exhibited the importance of literacy among individuals specifically in reading and writing. Moreover, it provides the status of students in reading and writing, which highlights the basic skills every student has to master as part of attaining a quality education. It is the primary concern of the Philippine education system to equip learners with the potential to read and write. As a result, the research helps the Department of Education (DepEd) achieve its primary goal of providing a high-quality education and mastery of basic academic literacy.

The findings will help teachers and curriculum administrators become aware of students' performance and attitudes in reading and writing. Also, it will improve teaching strategies and materials to support students' reading and writing mastery.

In addition, the creation of programs that will sustain learners' engagement in reading and writing activities will be possible at the initiative of the curriculum planners for a particular skill. At the same time, it will assist curriculum developers in developing more meaningful strategies for addressing issues with students' basic academic skills particularly the reading and writing macro skills.

\section{Literature Review}

\section{Reading Performance}

Reading comprehension is a foundation that strengthens an individual's ability to read. It encompasses the skills in reading that allow learners to apply different types of reading.

The Department of Education's Basic Education Curriculum aims to develop functionally literate graduates with the essential and expected skills for the twenty-first century. As a result, reading is taught in both public and private schools to help students develop a valuable reading habits. The ECARP (Every Child a Reader Program) and DEAR (Drop Everything and Read) programs, 
with the tagline "Reading Skills, Key to Learning," were created to prepare pupils with quick reading and writing skills. Additionally, these systems were used to supplement K-12 Curriculum subject offerings in order to build multiliterate and independent problem solvers. Reading and Writing is a core topic in the Senior High School curriculum that teaches students how to read and write in a variety of contexts other than poetry, fiction, and drama. It exemplifies key elements such as a) honing students' reading abilities through an in-depth discussion of reading and thinking strategies across text formats; 2) the ability to recognize text and context connections in a variety of reading resources; and 3) students' familiarity with writing as a complementary activity to reading. The subject intends to improve students' reading and writing habits by exhibiting them to academic and professional texts with applied applications in a real-life context (Ocampo, 2018).

In the digital society, literacy skills are essential. This progress human lifestyles by promoting growth through education and innovation. Countries with many students under the age of 15 who lack basic reading skills are likely to lag in the future. Investments aimed at improving literacy skills also benefit from an economic standpoint. They have a measurable impact on both individuals and society (OECD, 2013; the final report of the EU's high-level literacy expert group, 2012).

Castigador (2007) emphasized that reading is a remarkable skill for gathering knowledge obtained through comprehension and translation of written content obtained from various printed resources. Reading makes possibilities among individuals to communicate well and improves one's creativity, abilities, thoughts, imagination, and personality (Durualp et al., 2013; HughesHassell\& Ridge, 2007)

The habit of reading increases reading rate (Arcan\&YImaz, 2010; Arslan et al., 2009; Balc et al., 2012; Dreher, 2002). Positive and higher reading comprehension is an effect of increased time spent and progressive reading engagements (Guthrie \&Wigfield, 1999).

According to Bernardo (2009), reading is a form of nonverbal communication that helps us develop our vocabulary and knowledge. It is a useful learning tool for constructing meaning and acquiring new information (Pretorius, 2002). Furthermore, the foundation of education is for all learners, regardless of the level of expertise, because it offers the groundwork for future progress and achievement in all aspects of life (Scott 2010; Luckner\& affected by Handley 2008).

Understanding what you are reading helps learners to understand a text and to be able to interact and generate things from the text. However, fluency in reading with comprehension is also the basic element learner's academic success. Thus, it is an integral part of individuals and indispensable in the circle of the educational system.

However, according to lqbal et al. (2015), the key factors that affect students' poor reading comprehension are poor vocabulary, the habit of cramming without learning and understanding, just passing the examination without developing the skills, lack of multidisciplinary knowledge, poor sentence structure and tenses, and failure to use tactics to infer meaning from context.

As stated by Awe (2014), learners with reading problems develop a negative attitude towards reading. Hence, he suggested that schoolteachers must promote systematic patterning in reading skills that will enhance learners' reading development as they ascend the academic ladder.

Reading is an important skill for achieving educational success. It has been viewed as critical to academic success and is often emphasized in the curricula (programs) that constitute the initial steps of any course that helps learners to read and comprehend efficiently (Sünbül et al., 2010). Moreover, reading comprehension is critical. According to Tierney \&Readance (2005), it is the major goal of ESL/EFL learners to understand the things around them and encourage them to hesitate about the content of what they have read. That requires an interactive mental process between the texts and the readers; linguistic experiences, world knowledge, and topic knowledge.

According to lqbal et al. (2015), reading improves linguistic skills. It builds readers with an enriched vocabulary, writing models, and knowledge of different cultures and societies.

However, Ntereke and Ramoroka (2017) found in their study on the association between reading abilities and students academic achievement that underperforming students exhibited major reading challenges, such as trouble linking information in a text and difficulty understanding the texts they read. Also, Zulu (2005) discovered that learners struggle with advanced reading abilities, such as critical analysis in her study of students' reading abilities and the impact of an academic reading course on their reading abilities. 
In his study, Qashoa (2006) found that the most demotivating factors for students' difficulty with the subject of English were vocabulary, structures, and spelling.

Another study, conducted by Momani (2009) and Al Samadani\&lbnian (2015), found a strong correlation between the students' learning attitude in learning English and their academic success.

\section{Attitude towards Reading}

Yzer (2012) defined that attitude as a person's evaluation or belief in a thing and how favourable or unfavourable his or her performance is. Ajzen (2005) also believes that an attitude is an unobserved hypothetical construct that reflects and evaluates either positive or negative things.

As cited by Bastug (2014) from (Hood et al. 2012; House \& Prion, 1998), attitude is a topic that is frequently researched in educational settings and extensively highlighted in reading studies as a characteristic that predicts academic accomplishment. Thus, he stressed the importance of students' reading attitudes in affecting their accomplishment. According to Tunde-Awe (2014), a person who does not regard reading would never acquire a good attitude about it. In a similar line, Petscher (2010) and Seitz (2010) argue that students' good reading attitudes are a critical indicator of their reading ability.

Appropriate reading instruction and remediation are framed to improve students' reading attitudes (Ortlieb et al., 2012). KoliVehovec et al. (2014) affirmed that positive attitudes towards reading were positively correlated with the amount of reading and linked to reading performance (McKenna \&Kear, 1990; OECD, 2010b).

Learners will develop a good attitude toward reading as a result of their involvement in reading and enhance their reading achievement and literacy abilities (LaCour et al., 2013; McKenna et al., 1995). However, educators are aware that challenging texts to read will reflect a negative attitude among learners (Ganske et al., 2003). It is fundamental to attaining literacy and to improving struggling readers' attitudes towards reading. Teachers must be involved in curricular planning and instructional decisions (Guthrie et al., 2009; Marinak\&Gambrell, 2010).

Positive reading experiences encourage learners to continue reading (Mol\& Bus, 2011). However, students' unfavorable attitudes toward reading reduce their chances of improving their grades (Kush \&Wattkins, 1996; Kush et al., 2005; McKenna et al., 1995; Mol\& Bus, 2011; Urhahne, 2015).

De Guzman (2013) asserts that students who have positive feelings about reading but have negative thoughts are less likely to read. Hence, students' low reading frequency is due to their negative reading attitudes. Donaldson (2010) established a link between reading attitude and reading frequency, improving by increasing others.

\section{Writing Performance}

The importance of writing, according to Choi (2013), Li (2012), and Olanezhad (2015), allows people to express their thoughts, accomplishments, dreams, and opinions. It unites people from various origins and across boundaries by bridging the gap. As students are required to, it is a survival skill basically to learn, prepare assignments and projects, and interact with others.

For both first and second language students, Condon and Kelly-Riley (2004) considered writing a requirement of academic achievement and the most difficult language skill to learn (Umar \&Rathakrishnan, 2012).

Writing is a critical academic talent over the developmental lifespan, according to Ubbes et al. (2018), as well as a self-regulated human expression to determine one's sentiments and opinions. Tanyer (2015) claims it is the most critical network to transfer existing information across academic subjects. An initial step in academic writing is to take higher-level composition. For firstyear students, being proficient in writing can be a difficult process that entails several elements (Vocabulary, mechanics, citation processes, genre variants, and so on are examples).

According to David Nunan's definition in Afrin (2016), writing is the performance of delivering words or ideas to a medium. From sentences to paragraphs, it is the mental process of generating and expressing ideas. Success in relevant professions is contingent on students' ability to manage various writing types, such as summaries, essays, and reviews (Dudley-Evans and St. John, 2013). It is a strategy that native and nonnative speakers can use to uncover new ideas and abilities that improve writing quality by focusing on quality standards such as purpose, content, audience, organization, vocabulary, mechanics, punctuation, and spelling, among others things (Jahin\&ldrees, 2012).

According to Salem (2007), language learners struggle to write successfully due to their restricted lexicon, styles, cultural knowledge, and lack of expertise with second language argumentative methods. Perspectives of undergraduate English majors on writing were investigated. When they were asked to write, the majority of the students felt overwhelmed. As a result, students 
struggled to start and finish their papers. This revealed their lack of technical, compositional ability. As a result, they made major grammatical and mechanical errors.

Students have major challenges and weaknesses in employing proper lexical words, organizing thoughts, and grammar, according to Javed and Umer (2014). According to Darus and Ching (2009), the most common errors made by Chinese students are writing mechanics, tenses, prepositions, and subject-verb agreement. The other weak areas are articles, prefixes, suffixes, irregular verbs, prepositions, punctuation, and spelling.

In the business world and education, writing is a crucial communication ability (cf. Levy \&Murnane, 2004; Murnane\& Levy; National Governors Association Center for Best Practices, 2005). Writing, according to Sariyan (2004), is not just a pastime but also a profession. Many people utilize it as a means of communication. Bakar et al. (2011) also noted that successful writing promotes language register knowledge and appropriateness. Its progression entails the presentation of ideas, proper language use, grammar, elaboration, and paragraph development.

According to Lagayan (2018), writing composition activities help students enhance and guide their writing talents. Writing composition entails essay writing, analysis, and reaction to a certain subject, as well as just expressing one's feelings. The teacher permits free writing by students to fully convey their ideas at some point. On the other hand, learners struggle to master standard grammatical principles in English due to a lack of vocabulary and unclear sentences.

According to Alinsunod (2014), solid grammatical structures, adequate punctuation marks, suitable verb tenses, correct use of pronouns, and well-spelled words are some of the criteria for satisfaction in language learners' written work. The essentials of successful writing include paragraph writing with proper sentence structure, vocabulary, and spelling, which all contribute to the overall quality of the work (in Santangelo\&Olinghouse, 2009, p.16; Berninger\&Amtmann, 2003; Graham, Harris, \& Fink, 2000; Graham, Harris, \& Fink-Chorzempa, 2002). However, many students continue to make the same writing mistakes. Grammar is a common error that students make when writing their writing, according to Lagayan (2018). Prepositions, nouns, pronouns, and adverbs, among other parts of speech, were found to be misused in their sentences.

According to Ramos's (2019) study of first-year college students' common writing errors, the errors were grouped into eight grammatical categories: articles, agreements, tenses, pronouns, prepositions, incorrect word choice, spelling, singular and plural forms. Two significant factors that contributed to the presence of errors in students' written work were inter-lingual and intralingual transfer. General items (linguistic style and expression in particular), style, grammar, mechanics, lexical items, and syntax were found to be the most prevalent written errors by pupils, according to Bui Thui Tram (2010). Grammatical errors account for the majority of the common errors found. According to Cruz \& De Juan et al. (2007), pupils made more errors in English usage than in English structure. Run-ons appeared to be the most prevalent sort of English structure fault, while coordination/subordination appeared to be the least common. The most common use error was the subject-verb agreement error.

Apart from grammar, mechanics is another prevalent mistake made by most pupils. Umpa et al. (2019) describe mechanics in writing as standards of paragraphing, punctuation, spelling, capitalization, and handwriting are all factors that influence the text's grammatical and aesthetic value. However, according to Alfaki (2015), the lack of universally recognized punctuation norms is one of the reasons why people make punctuation mistakes. A similar explanation can be found in capitalization problems. The majority of pupils had substantial difficulty with simple present tense, passive voice, relative pronouns, use of adjectives, spelling, punctuation marks, and choosing appropriate vocabulary, according to Komba (2012) study.

According to Lasaten (2014), learners' common linguistic flaws in English works include errors in articles, choice of words, verb tenses, prepositions, sentence structure, punctuation, and spelling. These faults affect the grammatical, mechanical/substance, and syntactic components of writing English. The majority of these mistakes are the result of learners' weak familiarity with the target language, notably their lack of understanding of rule constraints. Others are brought on by the learners' carelessness, interference from their first language, and a restricted vocabulary in the target language.

However, according to Lagayan (2018), the students' obligation in language acquisition is to check for errors in their written discourse to increase effective communication.

\section{Attitude towards Writing}

This topic discusses how previous research and researchers have discussed writing attitudes and how they manifest themselves in writing among learners in various settings.

According to Forbes and Schomader (2010), student attitudes toward writing assessments may affect their willingness to learn. Writing can be utilized as a human self-regulatory expression to convey one's sentiments and opinions about a topic that is 
being read or presented. Young people can use writing to reflect on their personal health behaviours and consider their attitudes, reasons, and/or beliefs regarding their activities (Ubbes et al., 2018). According to Akkaya and Kirmiz (2010), pupils who favour writing expend more energy on work. Hence, writing attitudes were characterized by Williams (2012). According to Graham et al. (2007), writing is an affective state in which the author feels a variety of emotions ranging from pleasure to dissatisfaction.

Students' attitudes and their ability to read and write are inextricably linked (Cunningham, 2008). A student with a positive attitude toward writing, on the other hand, is more likely to organize writing activities, be more meticulous, persevere in the face of problems, set demanding goals, and believe in his or her own abilities (Bandura \& Graham, 2006). Students with a positive perspective are pro to writing than students who have a bad writing mindset. Furthermore, students with a positive attitude may choose to write even if it is not required. Students with negative attitudes may avoid writing assignments or write poorly (Graham et al., 2007).

Scholarly data recommends a few strategies that can help learners overcome their fear of writing, according to Ali and Kassem (2017). Non-graded writing assignments, for example, should be offered to students to assist them to overcome their fear of negative criticism (Clark, 2005). Peer feedback and self-correction should be viewed as an alternative to teacher feedback: the idea of writing as a process should be taken into account, students' voices should be acknowledged, and individual variances should be accepted (Rankin-Brown, 2006). Through collaborative work, students must overcome their apprehension and dread of writing. Working in groups to reduce fear is encouraged (Kurk\&Atay, 2007), and students should be provided with the criteria for evaluating their work.

According to Wang (2012), students with inferior creative performance dislike writing and only write when asked. According to Ayachi (2017), writing is often overlooked because it is both productive and time-consuming. As a result, bad grades on writing papers are frequently observed. Thus, writing, as a skill, should be considered in various segments.

\section{Conceptual Framework}

The Department of Education (DepEd) claims that quality education is the most important goal in curriculum implementation. Quality education promotes Filipino citizens' acquired literacy, specifically reading and writing literacy.

The tertiary institutions expect freshmen students to be products of the Senior High School program under the $\mathrm{K}$ to 12 Curriculum. These students are moving forward to courses that lead them to their preferred professions. Their reading and writing performance play a vital role in whether they achieve the target course or not. According to Mosha (2014), the level of mastery in terms of attitudes, production and comprehension is referred to as language performance. When predictor variables and mediator variables were favorable, the higher the performance; otherwise, the performance would suffer.

Reading and writing skills have been at a developing level among learners. These skills seem common among students as they develop them for 12 years in basic education, but many still struggle to read and write. This provided the researcher an initiative to determine students' performance and their attitude to these skills.

As cited by Ocampo (2018), the reader's organized knowledge supports the reader's comprehension, learning, and retaining the text's ideas. However, teachers should ensure appropriate interventions to address students' difficulty reading that help learners achieve high academic performance on the educational ladder.

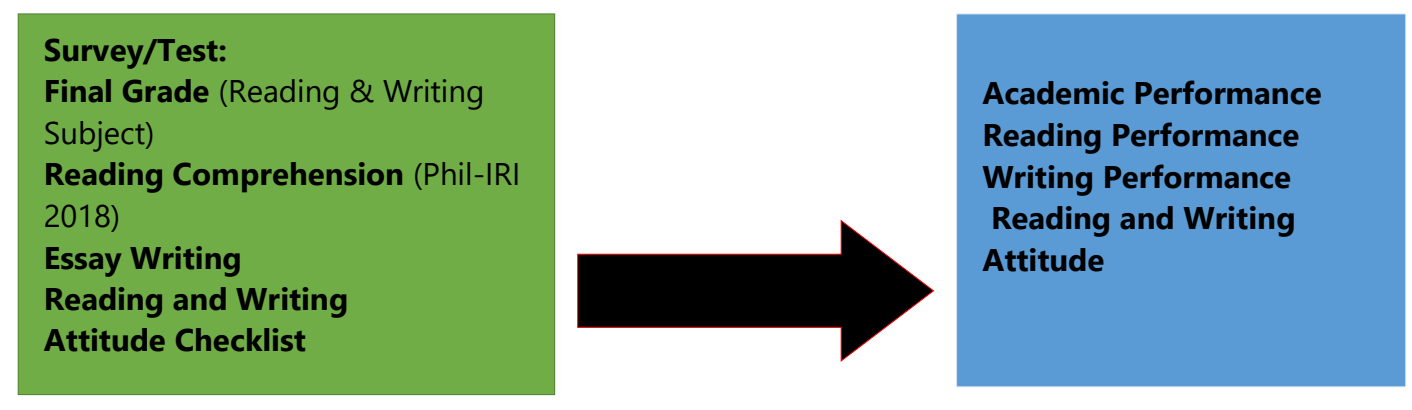

Figure 1: Conceptual Framework 


\section{Methodology \\ 3.1 Research Design}

A quantitative research design was utilized to assess the reading and writing performance of the learners and their reading and writing attitudes. The study dealt with the descriptive method where the students underwent a reading comprehension test and writing activity. A survey questionnaire was also used to identify students' attitudes to reading and writing.

\subsection{Participants of the Study}

The research is conducted in Delfin Albano High School - Main (Catabayungan), Delfin Albano High School Annex (San Juan), and Alfreda Albano National High School Main in Cabagan, Isabela (Magassi). The participants were senior high school students. Using a 5\% margin of error, 244 out of 670 Grade 12 students participated in the survey. They came from the Academic Track, specifically the Humanities and Social Sciences (HUMSS) strand, Accountancy and Business Management (ABM) strand, and Science, Technology, Engineering, and Mathematics (STEM) strand; and the Technical Vocational Livelihood (TVL) Track, specifically the Industrial Arts Strands [Shielded Metal Arc Welding (SMAW), Electrical Installation Maintenance (EIM), and Automotive]. The study's participants were chosen via proportional allocation - stratified random selection.

\subsection{Research Instruments}

To gather the data for the study, a one hundred-item objective test, a three-item question, and a checklist of reading and writing attitude were used.

A 100-item reading comprehension test adopted from Phil-IRI 2018 was prepared and administered to assess the reading performance of the respondents. On the other hand, three open-ended questions were given for students' engagement in writing. The outputs were assessed through a researcher-made rubric.

The Attitude Survey was also used by (Kolić-Vehovec, et al., 2014), was adopted, modified, and administered. Students estimated how they felt during reading using a 4-point scale ranging from 1 (highly unfavourable) to 4 (highly favourable).

\subsection{Data Gathering Procedure}

The primary goal of this research was to evaluate the respondents' reading and writing performance. The researcher himself personally administered the conduct of the study. The researcher was permitted by the head of the school to conduct the study and introduced the objective of the study among students to obtain full participation. The students underwent a 100-item reading comprehension test answered in one and a half hours. They were also given three questions to express themselves freely. The written outputs of the students were collected and checked accordingly using the researcher-made scoring rubric with the inter-rater checking participated by three in-service English teachers.

The reading and writing attitude survey questionnaires were also administered to the respondents. The researcher personally guided the respondents in answering the questionnaires to maintain the accuracy of the data to be collected. The data determined the attitude of the students towards reading and writing activities.

The attitude survey results were also used to determine the relationship between the students' attitudes towards reading and writing and their reading and writing performance.

The requested grades of the students in their Reading and Writing subject were added to the task to determine the students' academic performance in the subject.

The researcher collected, checked, and analyzed the outputs of the respondents from the sessions conducted.

\subsection{Statistical Treatment of Data}

Frequency counts, percentage scores, the arithmetic mean, and the Kendall's Rank Correlation Tau were used to describe and analyze the study's data.

The outputs were checked and interpreted using the criteria from the manual for the Philippine Informal Reading Inventory (PhilIRI) published in 2018.

A researcher-made rubric was used. The rubric highlights two indicators: Grammar such as Subject Verb Agreement, Antecedent, Modifier and prepositions and Mechanics such as Capitalization, Spelling and Punctuations. The students' written output was opted to be checked by at least three English teachers guided using the rubric.

Furthermore, the students' performance output was classified using the $\mathrm{K}$ to 12 Program's regular grading system. 


\section{Discussion}

\subsection{Reading Performance}

Table 1 : Percentage Distribution of Students based on their Reading Performance

\begin{tabular}{|l|l|l|}
\hline Reading Performance Level & $\mathrm{f}$ & $\%$ \\
\hline $80-100$ (Advanced) & 3 & 1.23 \\
\hline $59-79$ (Instructional) & 45 & 18.44 \\
\hline $58-$ below (Frustration) & 196 & 80.33 \\
\hline Total & 244 & 100 \\
\hline Overall Mean & 41 (Frustration level) & \\
\hline
\end{tabular}

One of the most critical abilities for academic achievement is reading. According to Tierney \&Readance (2005), it is regarded as one of the major goals for ESL/EFL students to achieve understanding of the world around them and of themselves and encourage them to hesitate about the contents of what they have read. Iqbal et al. (2015) also assert that reading skills help students write and speak well-structured and meaningful sentences, improving other linguistic skills. It builds readers with enriched vocabulary, textual models, and an understanding of many cultures and societies. The result on the reading performance of the students implies a poor performance.

Furthermore, Sünbül et al. (2010) stated that students who cannot read efficiently and comprehend what they read would not be successful. Thus, the result of the study is a serious problem needing immediate action.

\subsection{Writing Performance}

Table 2 : Percentage Distribution of Students based on their Writing Performance

\begin{tabular}{|l|l|l|}
\hline Percentage Score & $\mathrm{f}$ & $\%$ \\
\hline $90-100$ (Outstanding) & 0 & 0 \\
\hline $85-89$ (Very Satisfactory) & 0 & 0 \\
\hline $80-84$ (Satisfactory) & 1 & 0.41 \\
\hline $75-79$ (Fairly Satisfactory) & 5 & 2.05 \\
\hline 74 and below (Did Not Meet Expectation) & 238 & 97.54 \\
\hline Total & 244 & 100 \\
\hline Overall Mean & 54 (Did Not Meet Expectation) \\
\hline
\end{tabular}

Writing is a medium of communication and is considered a profession. Thus, an efficient writer needs to master the facets of writing (Lagayan, 2018).

However, learners struggled to write successfully due to a lack of expertise with second language rhetorical strategies, cultural awareness, and vocabulary. They were overwhelmed by the task of writing a specific topic and struggled to write passable English writings. As a result, there were numerous grammatical and punctuation problems, as well as unnecessary information (Salem, 2007).

As identified from the participants' writing, the errors committed by the senior high school students are presented below.

\subsection{Frequency of Errors Committed on Writing}

\begin{tabular}{|l|l|}
\hline Table 3 : Indicators & $\mathrm{f}$ \\
\hline Grammar & \\
\hline Modifier & 1,137 \\
\hline Subject-Verb Agreement & 1,113 \\
\hline Preposition & 1,065 \\
\hline Antecedent & 891 \\
\hline Mechanics & \\
\hline Capitalization & 2,263 \\
\hline Punctuation & 1,282 \\
\hline Spelling & 964 \\
\hline
\end{tabular}

\section{Subject-Verb Agreement}

The students failed to retain the distinction between subject and verb in terms of singularity and plurality. They still do not understand how verbs relate to topics. Grammar and structure, on the other hand, are critical in academic writing. Therefore, it is 
necessary to make sure that subjects and verbs always agree. In grammatically accurate English writing, the relationship between subjects and verbs is important. A sentence's subject-verb agreement merges it and enables clearer comprehension (https://www.enago.com/academy/make-subjects-verbagree/). Below are some examples of their mistakes.

"It happen when I'm in Grade 10"

"Before that I finish my study in SHS...I encounter many challenges"

"There are many experience in our lives that makes us happy or sad"

\section{Modifiers}

The Filipino context appears to have affected students' use of redundant modifiers. Afrin (2016) concluded that articles were sometimes used to over-correct written outputs among students. They used the word "very" twice as an adjective; another is "party-party song"; "so very proud". They also used double superlatives like "My most greatest achievement...". The improper use of articles was also observed, e.g., "I see myself an successful welder"..

\section{Use of Preposition}

Students had confusion about the proper use of prepositions. They misused the function of prepositions as linkers in writing compositions. The data further confirmed Lorincz's (2012) claim that prepositions are barriers to L2 learners due to their vast number and diversity. According to their study of learners' language output, substitution, addition, and omission are the most prevalent syntactic errors. Examples are shown below:

"...because my mother is there in together to join me..."

"I gave the gift on her"

"...we visited in my cousins..."

"...even we are on a poor family..."

\section{Antecedent}

Antecedent errors were the least of all the indicators in terms of grammar. In the students' work, it was the least type of error. However, in English grammar, the antecedent is significant since it clarifies each sentence for the reader. The sentence is useless and incomplete without the antecedent. In short, it intensifies the authors' writing style. Below are some examples.

"They won't know I hurt but I'll show them that their wrong."

"Every person has their own unforgettable moment in their life.'

\section{Capitalization}

The students were accustomed to writing proper nouns in lowercase, and the pronoun "l" beginning with a small letter. They were not careful about emphasizing the role of each word in their composition. Worst is the use of uppercase letters [f], e.g. "10 years From now, I see myselF as Future proFessional teacher." Like other errors, capitalization should also be addressed. Siddiqui (2015) underlined that new pedagogical strategies in capitalization instruction should be included in the English curriculum to promote mastery of capitalization principles, norms, and comprehension of the orthographic-linguistic-cultural conventions of the English language.

\section{Punctuation}

Run-on sentences were observed in the students' write-ups. They were also used to write long sentences without any presence of punctuation. Errors were mostly observed in writing complete addresses, appositives, apostrophes and ending the sentences with a period. Aksoy (2014) stressed the need to maintain clarity in our works and to avoid ambiguity in expression. A run-on sentence is a structural defect that can affect even the shortest sentences, and it should be avoided in all second-language writing.

\section{Spelling}

Many students continue to make spelling mistakes in their written work. This could be due to the students' insufficient exposure to the vocabulary terms. They make omission, addition, and replacement errors. "Athlete," "complition," "bussiness," "intrepreneur," "desission," and "expirience" are some of the words. On the other hand, Botley and Dillah (2007) emphasized that regular reading practice on the part of language learners would be a highly effective way of exposing students to a large number of examples of "correct" spellings, thereby assisting them in unconsciously avoiding spelling errors.

The table (Table 3) above demonstrated the errors committed by the students in writing. Among all the indicators, the study revealed that capitalization, punctuation (mechanics), modifier, SVA, and preposition (grammar) were the most errors committed in writing. The findings corroborated Cabansag's (2013) study, which found that most students make the most mistakes in the 
use of capitalization in their writing. Nevertheless, the bulk of the signs in grammar and mechanics were most of the faults, as seen in the study's findings.

Grammar plays a significant role in writing because it provides information that could help the reader's comprehension. Hence, eliminating errors in writing provides a clear message for both writer and reader. On the other hand, mechanics, like grammar, also convey information.

The result of the study which focused mainly on grammar and mechanics, concurs with the findings from the study conducted by Bui Thi Tram (2010). The study revealed six types of common written errors of the students, namely, grammar, style, general items (in particular, language style and expression), syntax, mechanics, and lexical elements. Grammatical errors were the most prevalent errors found which was surprising. Also, in the study conducted by Cruz and De Juan, et al. (2007) on identifying language students' errors, students made more mistakes in their English usage than they did in their English structure. Run-ons appeared to be the most prevalent sort of English fault, while coordination/subordination appeared to be the least common. The most significant error was the subject-verb agreement error.

Moreover, the result of the study also agrees with the findings cited by Bakar, et al. (2011) from the study of Mahamod, et al. (2008) that the most visible issues learners experience are those relating to language accuracy, such as spelling, punctuation, morphology, and syntax.

Students were also weak in using prepositions, spelling, irregular verbs, and articles (Javed and Umer, 2014) and writing without planning, making their output purposeless (Mustaque, 2014).

Thus, the result of the study is a serious problem that indicates students' poor writing performance.

\subsection{Students' Attitude towards Reading}

Table 4 : Percentage Distribution of Students according to their Attitude towards Reading

\begin{tabular}{|l|l|l|}
\hline Attitude & $\mathrm{f}$ & $\%$ \\
\hline $3.50-4.00$ (Highly Favorable) & 26 & 10.65 \\
\hline $2.50-3.49$ (Favorable) & 199 & 81.56 \\
\hline $1.50-2.49$ (Unfavorable) & 19 & 7.79 \\
\hline $1.00-1.49$ (Highly Unfavorable) & 0 & 0 \\
\hline Total & 244 & 100 \\
\hline Mean & 3.0 (Favorable) & \\
\hline
\end{tabular}

The students' positive attitude to reading indicates a positive mindset. This shows that students value reading, which may help them do better. According to Mol\& Bus (2011) research, children who love leisure reading read habitually and significantly improves their language and reading skills. Students' favorable reading engagements encourage them to continue reading but students' negative reading attitude lessen their opportunities forprogressive performance

Students with a negative reading mindset have lower interests to join in reading events and have a lesser ability to progress (Kush \&Watkins, 1996; Kush, et al.,2005; McKenna, Kear, et al., 1995; Mol\& Bus, 2011; Urhahne, 2015).

Table 5 shows the results of a survey on students' attitudes toward reading, with a grand mean rating of 3.02 indicating a positive attitude toward reading.

Table 5 : Mean and Description on Reading Attitude Survey

\begin{tabular}{|l|l|l|l|}
\hline \multicolumn{2}{|l|}{ Statements } & Mean Rating & Description \\
\hline 1 & How do you feel when you're reading a book during rainy days? & 3.09 & Favorable \\
\hline 2 & How do you feel reading during a break? & 2.87 & Favorable \\
\hline 3 & What are your thoughts on reading for pleasure at home? & 3.34 & Favorable \\
\hline 4 & How do you feel after receiving a book gift? & 3.08 & Favorable \\
\hline 5 & How do you feel reading a book during a vacant hour? & 3.08 & Favorable \\
\hline 6 & How do you feel reading a new book? & 3.13 & Favorable \\
\hline 7 & How do you feel reading over your summer break? & 2.86 & Favorable \\
\hline 8 & How do you feel shifting from playing to reading? & 2.85 & Favorable \\
\hline 9 & How do you feel about going to a bookstore? & 3.03 & Favorable \\
\hline 10 & How do you feel after reading a variety of books? & 3.22 & Favorable \\
\hline
\end{tabular}




\begin{tabular}{|l|l|l|l|}
\hline 11 & How do you react when a teacher quizzes you about what you've read? & 2.83 & Favorable \\
\hline 12 & How do you feel reading workbook pages and worksheets? & 2.79 & Favorable \\
\hline 13 & What are your thoughts on reading when you're in school? & 2.97 & Favorable \\
\hline 14 & How do you feel when you are asked to read schoolbooks? & 3.03 & Favorable \\
\hline 15 & How do you feel about earning knowledge from books? & 3.36 & Favorable \\
\hline 16 & When it's time to do reading in class, how do you feel? & 3.03 & Favorable \\
\hline 17 & How do you feel about reading stories in class? & 3.16 & Favorable \\
\hline 18 & How do you feel about reading aloud in class? & 2.78 & Favorable \\
\hline 19 & What are your thoughts on reading along with dictionary? & 3.00 & Favorable \\
\hline 20 & What are your thoughts about taking a reading test? & 2.86 & Favorable \\
\hline Overall Mean Rating & 3.02 & Favorable \\
\hline
\end{tabular}

Students' positive attitudes toward reading suggest reading to be a pleasurable activity (Karimabadi et al., 2015). Hence, learners with a good reading mindset would want to read, like reading, improve their reading skills, and become lifelong readers (NASP, 2004).

\subsection{Students' Attitude towards Writing}

Table 6 : Percentage Distribution of Students according to their Attitude towards Writing

\begin{tabular}{|l|l|l|}
\hline Attitude & $\mathrm{f}$ & $\%$ \\
\hline $3.50-4.00$ (Highly Favorable) & 32 & 13.11 \\
\hline $2.50-3.49$ (Favorable) & 191 & 78.28 \\
\hline $1.50-2.49$ (Unfavorable) & 16 & 6.56 \\
\hline $1.00-1.49$ (Highly Unfavorable) & 5 & 2.05 \\
\hline Total & 244 & 100 \\
\hline Mean & 3.02 (Favorable) \\
\hline
\end{tabular}

As illustrated in the conducted survey on the writing attitude of the students in Table 13 with the grand mean rating of 3.02 is favourable. Bustamante \&Eom (2017) emphasized that developing favorable students' writing attitude backs success in their education and future career and help them become more motivated to lead to academic success.

Table 7: Mean and Description on Writing Attitude Survey

\begin{tabular}{|l|l|l|l|}
\hline \multicolumn{2}{|l|}{ Statements } & Mean Rating & Description \\
\hline 1 & How do you feel about writing from someone else's perspective? & 2.92 & Favorable \\
\hline 2 & How do you feel about writing about something you have heard or seen? & 2.94 & Favorable \\
\hline 3 & How do you feel about checking your own written work? & 3.25 & Favorable \\
\hline 4 & How do you feel explaining to someone in writing? & 2.94 & Favorable \\
\hline 5 & How do you feel about writing during your free time? & 2.92 & Favorable \\
\hline 6 & How do you feel about writing a diary? & 3.06 & Favorable \\
\hline 7 & How do you feel about writing poetry for pleasure? & 3.01 & Favorable \\
\hline 8 & How do you feel about drafting a letter expressing your insight on a subject? & 3.11 & Favorable \\
\hline 9 & How do you feel being an author of certain books? & 3.26 & Favorable \\
\hline 10 & How do you feel being a writer for a newspaper? & 3.05 & Favorable \\
\hline 11 & How do you feel about being a better writer? & 3.09 & Favorable \\
\hline 12 & How do you feel about composing a story instead of doing your homework? & 2.87 & Favorable \\
\hline 13 & How do you feel about composing a story while watching TV? & 2.99 & Favorable \\
\hline 14 & How do you feel about your friends reading your work? & 3.07 & Favorable \\
\hline 15 & How do you feel about writing about your life experiences? & 3.15 & Favorable \\
\hline
\end{tabular}




\begin{tabular}{|l|l|l|l|}
\hline 16 & How do you feel about writing more in school? & 3.09 & Favorable \\
\hline 17 & How do you feel taking notes on significant points during discussion? & 3.10 & Favorable \\
\hline 18. & How do you feel about writing a lengthy story or report in school? & 2.87 & Favorable \\
\hline 19 & How do you feel your classmates discussing ways to improve their writing? & 2.99 & Favorable \\
\hline 20 & How do you feel your teacher is requesting you to revise your work? & 2.67 & Unfavorable \\
\hline \multicolumn{2}{|l}{ Overall Mean Rating } & 3.02 & Favorable \\
\hline
\end{tabular}

A student with a good writing mindset organizes writing activities, exerts more effort, perseveres in the face of obstacles, sets challenging targets, and believes in his or her own accomplishment (Bandura \& Graham, 2006). Hence, the more enthusiastic kids are about writing, the more time and effort they put into it (Akkaya\&Kirmiz, 2010).

\subsection{Academic Performance}

Table 8 : Distribution of Students according to their Academic Performance

\begin{tabular}{|l|l|l|}
\hline Final Grade & $\mathrm{f}$ & $\%$ \\
\hline $90-100$ (Outstanding) & 31 & 12.70 \\
\hline $85-89$ (Very Satisfactory) & 79 & 32.38 \\
\hline $80-84$ (Satisfactory) & 80 & 32.79 \\
\hline $75-79$ (Fairly Satisfactory) & 54 & 22.13 \\
\hline 74 and below (Did Not Meet Expectation) & 0 & 0 \\
\hline Total & 244 & 100 \\
\hline Mean & 84 (Satisfactory Level) \\
\hline
\end{tabular}

The students' satisfactory academic performance in the subject means that they have received a passing grade and have met the subject's standard requirement/s. This means that students are performing well academically, as no one is failing. On the other hand, students will be motivated to study more and reach high literacy levels due to the pressure to perform well.

\subsection{The Relationship between Students' Reading Performance and Attitude as well as their Writing Performance and Attitude}

Table 15 : Summary of Kendall Tau Rank Correlation Values

\begin{tabular}{|l|l|l|}
\hline Variables & Kendall Tau & P-Value \\
\hline Reading Performance and Reading Attitude & 0.1080854 & 0.01451 \\
\hline Writing Performance and Writing Attitude & 0.1419704 & 0.001929 \\
\hline
\end{tabular}

The study determined that reading comprehension and reading attitude with a P-Value of 0.0145 , which is less than 0.05 , have a positive relationship. This implies that students' reading comprehension and their reading attitudes are significantly associated. The result parallels Karimabadi et al. (2015) findings that reading comprehension is positively correlated with high motivation for reading. Readers with a positive attitude read more and find reading an interesting experience, while readers with a negative attitude read less and find reading boring. However, Bastug (2014) asserted that reading attitude has a strong predictor of reading comprehension.

The students' writing performance and attitude, on the other hand, exhibit a positive correlation with a P-Value of 0.0019, which is likewise less than 0.05 . This suggests that students' writing abilities are linked to their attitudes about writing. According to Graham et al. (2007), pupils with a positive writing perspective write more than those with a negative writing mindset. Furthermore, learners who have a positive mindset may choose to write even if it is not compulsory.

Students who have negative writing mindsets, on the other hand, may avoid writing assignments and put in little effort when doing so.

Thus, as cited by Ayachi (2017) writing is often overlooked because it is both productive and time-consuming. As a result, bad grades on writing papers are frequently observed. Thus, writing, as a skill, should be considered in various segments.

\section{Conclusion}

The study investigated the students' reading and writing performance as well as their attitudes toward reading and writing. This gave interest to the researchers because reading and writing are basic academic skills that learners must master, and the subject "Reading and Writing" is included in the Senior High School Curriculum. However, the results of the research will give curriculum 
planners an idea of what changes and improvements should be made to maintain the high level of education that the Philippine educational system can provide.

The findings of the study showed that the students are under a level of frustration in their reading performance following the standards of the Manual for the Philippine Informal Reading Inventory (Phil-IRI) 2018. According to the senior high school program's regular grading system, the students did not satisfy the requirements of the writing activities. The study's findings revealed that the majority of students made mistakes in their writing efforts, which is a serious issue. This suggests that the students' writing skills are lacking.

The students' academic achievement in the area of Reading and Writing is satisfactory. The attitude of the students towards reading and writing activities is favorable, which means a positive attitude. However, students' attitudes toward reading have a substantial impact on their reading performance, as well as their attitude toward writing has a substantial impact on their writing performance.

Thus, reading and writing are skills that help individuals become more literate. Immediate action in response to students' poor reading and writing performance will improve educational quality. Hence, suggesting programs and/or activities to improve or empower pupils' reading and writing abilities.

Despite their low performance, their positive attitude will help them improve their performance on the mentioned skills. Thus, resolving the issue will be sufficient to meet the Department of Education's major goal of producing quality Filipino learners who will be known globally and prepared to play a larger role in 21 st-century learning. Hence, the findings of the study will also be a reference for further research on reading and writing performance as a help to improve the English curriculum.

\section{References}

[1] Afrin, S. (2016). Writing Problems of Non-English Major Undergraduate Students in Bangladesh: An Observation. Open Journal of Social Sciences, 4, 104-115. http://dx.doi.org/10.4236/jss.2016.43016

[2] Al Samadani, H. \&lbnian, S. (2015). The Relationship between Saudi EFL Students' Attitudes towards Learning English and their Academic Achievement. International Journal of Education and Social Science,2(1),92-100. www.ijessnet.com

[3] Ali, M. \&Kassem, M. (2017). Developing Business Writing Skills and Reducing Writing Anxiety of EFL Learners through Wikis. English Language Teaching, 10(3), 151-161. doi: 10.5539/elt.v10n3p151

[4] Aksoy. A. (2014). The Effectiveness of Explicit Grammar Instruction on Avoiding Run-On Sentences. Global Journal on Technology. 6 pp 71 76.

[5] Anggraini, S. (2017). The Correlation Between Reading Comprehension and Academic Achievement of English Education Study Program Students of UIN Raden Fatah Palembang. [Unpublished Thesis]. Islamic State University, Raden Fatah Palembang.

[6] Ayachi, Z. (2017). Peer and Teacher Assessment in EFL Writing Compositions: The Case of Advanced English Major Students in Jendouba, Tunisia. The Reading Matrix: An International Online Journal,17(1), 156-166.

[7] Ayhan, A., Şimşek, S., \&Biçer, A. (2013). An analysis of children's attitudes towards reading habits. Contemporary Studies in Education, 1318. European Journal of Research on Education. http://iassr.org/journal

[8] Bakar, N., Awal, N., \&Jalaluddin, N. (2011). Investigating Malay Language Writing Proficiency Level Among Upper Secondary School Students. Journal of Language Studies, 11(2), 39-50.

[9] Bastug, M. (2014). The Structural Relationship of Reading Attitude, Reading Comprehension and Academic Achievement. International J. Soc. Sci. \& Education, 4(4), 931-946.

[10] Boerma, I. (2015). Teacher Perceptions Affect Boys' and Girls' Reading Motivation Differently. Reading Psychology, 33,1-23, doi: 10.1080/02702711.2015.1072608

[11] Botley, S. \&Dillah, F. (2007). Investigating Spelling Errors in a Malaysian Learner Corpus. Malaysian Journal Of ELT Research. 3 ISSN: $1511-$ 8002

[12] Bustamante, A. \&Eom, M. (2017). Linguistically Diverse Students' Attitudes Towards Writing in English. Texas Journal of Literacy Education, $5(1), 44-53$.

[13] Cabansag, J. (2013). Written Language Proficiency of Laboratory High School Students in A State University in Cagayan Valley Philippines. International Refereed Research Journal, 4(2), 87-93.

[14] Cekiso, M. \&Madikiza, N. (2014). Reading strategies used by Grade 9 English Second Language learners in a selected school. Reading\& Writing,5(1), Art. \#42, 1-7. http://dx.doi.org/10.4102/rw.v5i1.42

[15] Cekiso, M. (2012). Effects of strategy instruction on the reading comprehension and strategy awareness of Grade 11 English Second Language learners in the Eastern Cape. Reading\& Writing,3(1), Art. \#23, 1-8. http://dx.doi. org/10.4102/rw.v3i1.23

[16] De Guzman, M. (2013). Reading in the Digital Age: AdZU Grade School students' attitudes toward reading and the reading programs. Periodipost, 2, 1-3. Ateneo Research CenterEshghinejad, S. (2016). EFL students' attitudes toward learning English language: The case study of Kashan University students. Cogent Education,3(1236434). http://dx.doi.org/10.1080/2331186X.2016.1236434

[17] Gholaminejad, R., Moinzadeh, A., Youhanaee, M., \&Ghobadirad, H. (2013). Writing Attitudes of Iranian EFL Students: A Qualitative Study. Journal of Language Teaching and Research, 4(5), 1138-1145.doi:10.4304/jltr.4.5.1138-1145 
[18] Hanane, D. (2015). Students' Attitudes towards Academic Writing: Challenges facing EFL Learners - Case of study: Third year LMD students at Biskra University [Dissertation, Ministry of Higher Education and Scientific Research Mohamed Kheider University of Biskra].

[19] Huwari, I. \&AI-Khasawneh, F. (2013). The Reasons behind the Weaknesses of Writing in English among Pre-year Students' at Taibah University. English for Specific Purposes World, 14(38). http://www.esp-world.info ISSN 1682-3257

[20] Imam, O. A. et al. 2014.Reading Comprehension Skills and Performance in Science Among High School Students in The Philippines. Asia Pacific Journal of Educators and Education,29, 81-94.

[21] Iqbal, M., Noor, M., Muhabat, F. \&Kazemian B. (2015). Factors Responsible for Poor English Reading Comprehension at Secondary Level. Communication and Linguistics Studies, 1(1), 1-6. doi:10.11648/j.cls.20150101.11

[22] Javid, C. Z. \&Umer, M. (2014, March 4-5). Saudi EFL Learners' Writing Problems: A Move Towards Solution [Conference Session]. Global Summit on Education, Kuala Lumpur, Malaysia. E- ISBN 978-967-11768-5-6. WorldConferences.net

[23] Karimabadi, M., Khonamri, F. \&Mahdavi, O. (2015). Investigating Iranian Students' Attitude toward Using Collaborative Strategic Reading in their Reading Course. WALIA Journal, 31(S3), 260-265.

[24] Kirmizi, F. (2009). The Relationship between Writing Achievement and the Use of Reading Comprehension Strategies in the $4^{\text {th }}$ and $5^{\text {th }}$ Grades of Primary Schools. World Conference on Educational Sciences, Turkey [Conference Session]. Procedia - Social and behavioral Sciences, 230-234. doi:10.1016/j.sbspro.2009.01.042

[25] Kolić-Vehovec, S. Zubković, B. \&Pahljina-Reinić, R. (2014). Development of Metacognitive Knowledge of Reading Strategies and Attitudes Toward Reading in Early Adolescence: The Effect on Reading Comprehension. Psychological Topics,23 (1), 77-98, UDC - 159.946.4.072053.6

[26] Komba, S.C., Kafanabo, E.J., Njabili, A.F. and Kira, E.S. (2012). Comparison between Students' Academic Performance and their Abilities in Written English Language Skills: A Tanzanian Perspective. International Journal of Development and Sustainability, 1(2), 305-325.

[27] Lagayan, M.I. (2018). Error Analysis on English Written Discourse of 4th Year Mass Communication Students at Isabela State University Echague Campus. International Refereed Research Journal,9(2), 167-186.doi: http://dx.doi.org/10.18843/rwjasc/v9i2/23

[28] Lasaten, R. (2014). Analysis of Errors in the English Writings of Teacher Education Students. International Refereed Research Journal, 5(4), 92-101.

[29] Manuscript Drafting: Why is Subject Verb Agreement Important? https://www.enago.com/academy/make- subjects-verbagree/

[30] Merisuo-Storm, T. \&Soininen, M. (2014). The Interdependence between Young Students' Reading Attitudes, Reading Skills, and SelfEsteem. Journal of Educational and Social Research, 4(2), 122-130. Doi:10.5901/jesr.2014.v4n2

[31] Mosha, M. (2014). Factors Affecting Students' Performance in English Language in Zanzibar Rural and Urban Secondary Schools. Journal of Education and Practice, 5(35), 64-76. ISSN 2222-288X, www.iiste.org

[32] Muslim, I. (2014). Helping EFL Students Improve their Writing. International Journal of Humanities and Social Science, 4(2), 105-112.

[33] NASP, (2004). Reading - Encouraging Positive Attitudes: Strategies for Parents and Teachers, nasponline.org

[34] Ntereke, B. \&Ramoroka, B. (2017). Reading competency of first-year undergraduate students at University of

[35] Botswana: A case study. Reading\& Writing- Journal of the Reading Association of South Africa,8(1), 1-11.

[36] https://doi.org/10.4102/rw.v8i1.123

[37] Ocampo, D. (2018). Effectiveness of Differentiated Instruction in Reading Comprehension Level of Grade 11 Senior High School Students. Asia Pacific Journal of Multidisciplinary Research, 6(4), 1-10. www.apjmr.com

[38] Paz, P. (2018). Reading Comprehension Levels in English among Grade 7 Students in Caraga State University,

[39] Philippines. Education, 8(1), 5-8. DOI: 10.5923/j.edu.20180801.02

[40] Ramos, A. (2019). Common Writing Errors of First Year College Students. International Journal of Advanced Research in Management and Social Sciences, 8(6), 102-118. www.garph.co.uk

[41] Rezaeiantiyar, F. \&Khoshsima, H. (2014). The Effect of Presentation Strategy on Reading Comprehension of Iranian Intermediate EFL Learners. Advances in Language and Literary Studies, 5(3), 101-111.

[42] Seitz, L. (2010). Student Attitudes Toward Reading: A Case Study. Journal of Inquiry \& Action in Education, 3(2), 30-44.

[43] Siddiqui, M. (2015). Evaluating Capitalization Errors in Saudi Female Students' EFL Writing at Bisha University. Arab world English Journal,6(1), 232-250.

[44] Suacillo, C., Um, S., Velasquez, J., Villaflores, H. \&Cequena, M. (2016). Critical Reading Strategies, Reading Comprehension and Writing Performance of ESL College Students: A Correlational Study. International Journal of Advanced Research, 4(9), 610-623. http://dx.doi.org/10.21474/IJAR01/1526

[45] Tanyer, S. (2015). The role of writing and reading self-efficacy in first-year pre-service EFL teachers' writing performance. Procedia - Social and Behavioral Sciences, 199, 38-43. doi: 10.1016/j.sbspro.2015.07.484

[46] Tarnanen, M. \& Aalto, E. (2013). Studying in Comprehensive School with Low Second Language Writing Proficiency. Apples - Journal of Applied Language Studies, 7(1), 83-97. http://apples.jyu.fi

[47] Tulabut, R., Guzman. R., Abaring. P.R., Armada, A., llustre, A., \&Torda, M.J. (2018). Common Errors in Prepositions Committed by Grade 9 Students: Implications for Teaching. TESOL International Journal, 13(3) 113-123. ISSN 2094-3938

[48] Tunde - Awe, B. (2014). Relationship between Reading Attitudes and Reading Comprehension Performance of Secondary School Students in Kwara State, Nigeria. Review of Arts and Humanities, 3(2), 203-215. American Research Institute for Policy Development

[49] Ubbes, V., Dillhof, R. \& Maldonado, W. (2018). Reading and Writing Attitudes of Children: Conceptual Implications for Health Education and Health Literacy. Journal of Health Education Teaching, 9(1), 49-67. www.jhetonline.com

[50] Umpa, J., Batalon, C., Guimba, W., Tamano, R. \&Alico, J. (2019). Writing Error Remediation through Guided Writing Strategy: A Mixed Methods Probe. International Refereed Social Sciences Journal, 10(1), 42 - 59. http://dx.doi.org/10.18843/rwjasc/v10i1/05

[51] Williams, A. \&Ortlieb, E. (2014). Reading Specialists' Perceptions and Pedagogical Practices towards Struggling Readers. International Journal of Education,6(2), 82-97.: http://dx.doi.org/10.5296/ije.v6i2.5425 